\title{
Investigating the Factors Fostering Sustainable Collaboration between Japanese Companies and UK Universities
}

\author{
Yumiko Myoken ${ }^{1}$ \\ ${ }^{1}$ Science and Innovation Section, British Embassy Tokyo, Tokyo, Japan \& National Graduate Institute for Policy \\ Studies (GRIPS), Tokyo, Japan \\ Correspondence: Yumiko Myoken, Science and Innovation Section, British Embassy Tokyo, 1 Ichiban-cho, \\ Chiyoda-ku, Tokyo 102-8381, Japan. Tel: 81-3-5211-1328. E-mail: yumiko.myoken@fco.gov.uk
}

Received: April 12, 2014

Accepted: April 29, 2014

Online Published: May 5, 2014

doi:10.5430/ijba.v5n3p108

URL: http://dx.doi.org/10.5430/ijba.v5n3p108

\begin{abstract}
Under fierce global competition in a knowledge-based economy, Japanese companies based in the UK have intensified research and development (R\&D) collaboration and have been expanding their networks with excellent local universities and research institutes. Through administering questionnaires and interviews, this study attempts to clarify how Japanese companies absorb capacities by carrying out advanced R\&D with local universities and what benefits and spillover affect the UK academics. The results indicate that the Japanese companies located geographically close to excellent research environments are more satisfied with the outcomes of their collaborative R\&D with UK universities. Further, those companies have developed their organisational capacity by embedding themselves into the local innovation network. Moreover, UK academics have gained funding opportunities as well as research capabilities with an entrepreneurial mind-set through the intensifying collaboration with Japanese companies.
\end{abstract}

Keywords: Japanese global companies, strategic R\&D, UK-Japan collaboration, university-industry linkages, knowledge management, determinants for partnership, technology transfer

\section{Introduction}

Japan is widely perceived as a frontrunner in the field of advanced technology, which largely relies upon their intensive in-house R\&D with large amounts of research investment. However, faced with continuous economic recession over a decade, Japanese multinational companies that have engaged in knowledge-intensive R\&D have become increasingly keen to find the best research partners from academia and go abroad to conduct international collaborative R\&D. Such companies that own their R\&D abroad are greatly influenced by the distinguished innovation systems in the host country.

Expenditures on UK R\&D by foreign-owned companies exceed those of domestically owned firms. The UK is an attractive destination for foreign R\&D investment. With a strong science base, the UK is one of the most popular partners for R\&D collaboration, demonstrated by the large amount of R\&D investment from abroad. In 2011, the UK attracted about $\$ 7$ billion in overseas-financed $R \& D$. This is about the same as the combined figure for Canada, Finland, Japan, China, and Russia. While the amount of R\&D financed from overseas has increased in all sectors over the past decade, the most consistent increase has been observed in the higher education sector between 2000 and 2011.

Continued efforts have been made to develop positive, open and mutually supportive relationships with a range of countries around the world, both to encourage investment in the UK and to enable UK businesses to export. The UK has remained the top destination for Japanese companies in Europe. Over the past twenty years, the number of Japanese companies that have established R\&D centres in the UK has steadily increased. Inward investment from Japanese companies is perceived as a catalyst for creating new jobs and economic growth, as well as promoting knowledge-based innovation.

While the expansion of collaborative R\&D is led by Japanese companies and UK universities, there is a lack of understanding in greater detail the outcome of such R\&D. An intriguing question is related to which Japanese companies obtain high productivity and commercial as well as technological and scientific value from such 
collaboration. Moreover, the specific factors encouraging local academics in the UK universities to work with Japanese companies and the scientific and educational benefits they achieve have not been fully examined by previous studies.

With such a view in mind, this paper attempts to elucidate how location determines the pattern of collaboration and how it affects the level of satisfaction in terms of innovative research and commercial benefit for the Japanese companies as well as for their academic partners. This approach provides us a rich understanding of the open innovation system of global firms involved in collaborative R\&D linked with local higher education institutes abroad. In response to the significant issue of how global companies fit within R\&D strategies and the host innovation system, the author looks into the different patterns of collaboration and advantages for those companies based on innovation hot spots in the UK.

The author conducted a survey by distributing questionnaires to 153 Japanese companies located in the UK with support from British Embassy Tokyo and Japanese Chambers of Commerce. Then 23 companies are identified as the most proactive in terms of collaborative R\&D with UK local universities. Those companies are classified by different locations in order of geographically closeness from partnering HEIs; 1) on campus, 2) on science parks, and 3 ) independent site. Then the statistical analysis of non-parametric analysis, specifically the Mann-Whitney test and Principle Components Analysis (PCA) for categorical data are applied in order to elucidate incentive factors to identify the academic partners and examines the positive impact of geographical closeness on overall R\&D and commercial affairs. Moreover, the result of interviews with six most experienced university professors involved with such collaboration observes strong win-win relationships through knowledge transfer.

The next section starts by addressing previous studies on international $R \& D$ in general and then focuses on the most recent case study discussing Japanese multinational companies' strategies in terms of geographical proximity. The following section delineates the performance of Japanese companies based in the UK drawn from the survey questionnaire and interviews.

\section{Literature Review}

The development of international $\mathrm{R} \& \mathrm{D}$ collaboration takes place as market uncertainty increases, technology life cycles shorten, R\&D cost rises, and the technical scope of products broaden. It is no doubt that the success of global companies' activities, in particular, those in industrialised countries in largely ascribed to the internationalisation of collaboration in the area of R\&D. The growing role of internationalisation of R\&D certainly causes political concerns because the international partial externalisation of innovative activities through inter-firm partnerships inevitably triggers a tension between international partnering, benefiting from foreign capabilities (Duystaers and Hagedoorn, 1996). Ostry and Nelson (1995) coins the term of techno-nationalism and techno-nationalism to delineate the coexistence of conflict and cooperation in international R\&D.

As a growing knowledge-based economy over the last decade, global major companies used to have an in-house R\&D centres increasingly recognise the need for open innovation by outsourcing their basic scientific research. Japanese major companies are no exceptions and continuously strive to find the best academic partners in abroad, intensifying internationalisation of $\mathrm{R} \& \mathrm{D}$ collaboration with an aim to comprehend new technologies to acquire knowledge spill overs.

International $\mathrm{R} \& \mathrm{D}$ flows and collaborations are increasingly important phenomena in formulating innovation systems, and the UK is well placed to gain from an increase in international R\&D activity. Internationalisation of R\&D has been happening in the UK for some time and is steadly increasing trend (Bloom and Griffith, 2001). The UK is unique amongst the G8 countries in the share of its business expenditure on R\&D that is financed from abroad. Foreign firms in the UK appear to be relatively more R\&D intensive than foreign firms based in other G8 countries. Existing data on foreign investment in UK R\&D activity show that the UK has been an important location for MNEs and their associated knowledge investments (OECD, 2012).

As a growing number of internationalisation of R\&D led by global companies, some of recent studies significantly depict their distinguished business manner. For instance, Asakawa's study looks into Japanese companies, which maintain their R\&D laboratories in Europe. The analytical approach devised by Asakawa makes it possible to evaluate management strategies in international $R \& D$, specifically the relationship between parent companies and subsidiaries and the autonomy of both parties $(1996 ; 2001)$. His approach provides a useful analytical tool to re-examine the network structure, including the structure of linkages within and outside companies. It can also be used to evaluate capacity building (absorption capacity, conversation capacity and combining capacity) and 
demonstrate aspects of knowledge retention and mobility in a given network structure, specifically the level of network density and contingence.

Since the early 2000s, an increased number of studies have explored the enterprises' strategies towards knowledge management and open innovation by working with excellent science base in higher education institutes. UK universities with excellent research base have been successfully attracting industrial R\&D activities companies. Especially chemical and pharmaceutical companies are more proactive in working with top scientists and engineers while automobile and manufacturing companies show a modest level of interests (Abramovsky, Harrison, Simpson, 2007). Looking into the case of Japan's university-business collaboration led by the University of Tokyo, one study succinctly delineates incentives behind such collaboration and its impact on scientific research capabilities as well as the pattern of knowledge transfer under the transitional period of institutuional change in Japan (Suzuki, Goto, Baba 2007).

A. Lam (2003) succinctly clarifies the differences in managing organisational learning between globalised US and Japanese ICT and pharmaceutical companies' laboratories based in the UK. Through interviews with senior representatives affiliated with R\&D laboratories in the UK, the study shows that the nature of Japanese companies' links with local universities is characterised as being more aggressive or targeted players while the nature of US companies is more like that of collegial players.

More recent study focused on Japanese subsidiaries in 15 different countries concludes that those conducting basic and applied R\&D in abroad are concentrated in the certain countries whose share of R\&D over GDP is relatively high and featured by high knowledge capabilities (Shimazutani and Toda, 2008). With a similar research interests to illuminate the determinative factors of Japanese companies, it is empirically demonstrated that the research quality of local universities as well as good environment for industry-business collaboration in the host country have a great influence on final decision-making where to conduct R\&D (Suzuki, Belderbos, Hyeog \& Fukao, 2012).

Relied upon the previous work as mentioned above, this paper attempts to provide addiotional insights related to Japanese global companies' organisational mechanisms and strategic processes pertinent to R\&D internationalism. The study also clarifies factors quantitatively and qualitatively that underpin robust bilateral science-based linkage and affect the course of existing collaboration. Through locating their R\&D geographically close to universities, it can be hypothesised that Japanese companies intend to gain benefits by supplying a skilled local labour force of scientists and engineers as well as useful information and knowledge. The following paragraphs show the result of questionnaire that is designed to assess the level of benefits obtained by respective company.

\section{Result of Survey Questionnairs and Interviews}

\subsection{Performance of the Japaneese Companies}

In order to grasp the ongoing university and business collaboration between Japanese companies and local UK universities, the questionnaire was sent out to 153 Japanese companies with support from the Japanese Chamber of Commerce and Industry in the UK and the British Embassy Tokyo. In order to raise a response rate, the author directly contacted those companies deeply involved with collaborative R\&D with local HEIs.

The original survey was composed of 26 questions designed to investigate basic company information such as the number of years the company has been in business, the number of employees, and the type of business. Additionally, the questionnaire explored whether they have links with UK universities and, if so, what type of collaboration they are doing, what benefits they gain from such collaborations, and what factors concern them most when selecting their partner universities.

The questionnaire was distributed by the Japanese Chamber of Commerce in May 2012. The response rate was about $31 \%$; 46 companies out of 153 replied to the questionnaire. The respondents include 23 Japanese largest companies in ICT, Automobile, Pharmaceutical, Chemical, and Manufacturings and Equipments in terms of R\&D expenditure overall and they are all very keen to expand collaborative R\&D with local UK universities, playing as hub of European innovation network. The table 1 shows the list of all companies classified by their location: on campus; those as tenants of science parks; and those companies established on an indendent site. This paper applies the statistical analysis of non-parametric analysis, specifically the Mann-Whitney test and Principle Components Analysis (PCA) for categorical data to elucidate incentive factors to identify the academic partners and examines the positive impact of geographical closeness on overall R\&D and commercial affairs. 
Table 1. Classification of 23 companies

\begin{tabular}{ll}
\hline $\begin{array}{l}\text { Classification } \\
\text { Id number }\end{array}$ & \multicolumn{1}{c}{ Sector } \\
\hline Companies on University Campus (C) & \\
1 & Information Communication Technologies (ICT) \\
2 & Pharmaceuticals \\
3 & Biotech \\
\hline Tenant Companies on Science Park (S) & \\
4 & ICT \\
5 & ICT \\
6 & ICT \\
7 & Automobile \\
8 & Chemical \\
9 & Automobile \\
10 & ICT \\
11 & Pharmaceuticals \\
\hline Companies at Independent Site (I) & \\
12 & ICT \\
13 & Heavy industry/construction \\
14 & Chemical \\
15 & ICT \\
16 & Pharmaceuticals \\
17 & Electronics and manufacturing \\
18 & Telecommunications \\
19 & Manufacturing \\
20 & Chemical \\
21 & Machines and equipment \\
22 & ICT \\
23 & Manufacturing \\
\hline
\end{tabular}

(Source: Author)

Twelve of the 23 companies which have R\&D collaboration with local universities are electronics and communication firms. About $74 \%$ were established more than 16 years ago, which implies that they moved in the late 1990s when inward investment from Japan to the UK became popular. One of the questionnaires asked how they determined partnering universities. The majority of companies replied that they relied on internal personal linkages. Moreover, about $60 \%$ (14 companies) replied that they were willing to intensify collaboration in near future. The results of the questionnaires shows that Japanese tenant companies in science parks and those on university campuses have a strong tendency to carry out collaborative R\&D with local HEI over longer time spans compared to those at independent site identified as I companies.

As shown in Tables 2 and 3, principle component 1 shows the level of overall R\&D benefits as demonstrated by the large absolute number of coefficients in several items, such as highly qualified human resources, vitalise the company, and upgrade the quality of researchers, in addition to technology transfer from local HEI. Principle component 2 showed business and marketing benefits demonstrated by the large absolute number of coefficients in several items, such as accelerate the commercialisation of products and marketing. Table 1 depicts the ability of description to reach a relatively high ratio of $68.9 \%(=7.571 / 11)$ combined with principle component 1 at $46.5 \%$ $(=5.120 / 11)$ and dimension 2 at $22.2 \%(=2.450 / 11)$.

Table 2. Calculation of model

\begin{tabular}{lcc}
\hline Dimension & Cronbach's a & Variance of exposition/Total (Eigenvalue) \\
\hline 1 & .885 & 5.120 \\
2 & .651 & 2.450 \\
Total & $.955 \mathrm{a}$ & 7.571 \\
\hline
\end{tabular}

Note: Total $\alpha$ of Cronbach's alpha is based on total eigenvalue, which means the index indicating variables 
Table 3. Component loading

\begin{tabular}{|c|c|c|}
\hline \multirow{2}{*}{$\begin{array}{l}\text { Answer options } \\
\text { Highly equalified human resource }\end{array}$} & \multicolumn{2}{|c|}{$\begin{array}{l}\text { Dimension } \\
\text { omponent 1/ Principle Component 2) }\end{array}$} \\
\hline & .801 & -.023 \\
\hline Accelerate the commercialisation of products & .534 & .707 \\
\hline Marketing & .560 & .726 \\
\hline New ideas for product development & .768 & .444 \\
\hline Obtaining patent rights & .722 & -.324 \\
\hline Financial aid & .655 & .210 \\
\hline Technology transfer from local university & .769 & -.489 \\
\hline Newtorking/interaction with local companies & .522 & .440 \\
\hline Establish a network to gain information related to $R \& D$ & .436 & -.552 \\
\hline $\begin{array}{l}\text { Get new ideas that can be difficult to find in your } \\
\text { Company }\end{array}$ & .723 & -.457 \\
\hline $\begin{array}{l}\text { Vitalise your company and grade up the quality of } \\
\text { researchers }\end{array}$ & .856 & -3.58 \\
\hline
\end{tabular}

(Source: Author)

In this analysis, Principle Components Analysis (PCA) is a tool for identifying patterns in data and expressing the data to highlight similarities and differences. Since patterns can be hard to find in data of high dimension, where the luxury of graphical representation is not available, PCA is a powerful tool for analysing data. Also it should be noted that one of the main purposes in PCA intends to show the degree of data compression.

Figure 1 illustrates the levels of satisfaction of all 23 companies. The horizontal axis reflects the R\&D benefits and the vertical axis reflects marketing and business benefits. The figure shows that three companies on campus classified as 1 through 3 appear on the right side on the horizontal axis and in the middle position on the vertical axis, which is similar to the other companies. This result indicates that the companies on campus experiences higher levels of satisfaction in terms of overall R\&D benefits although satisfaction with commercial and business benefits remained at the average level. With the exception of one company categorised as a science park tenant, who expressed the lowest level of research and business benefits, majority of companies on campuses and in science parks showed steady overall higher satisfaction.

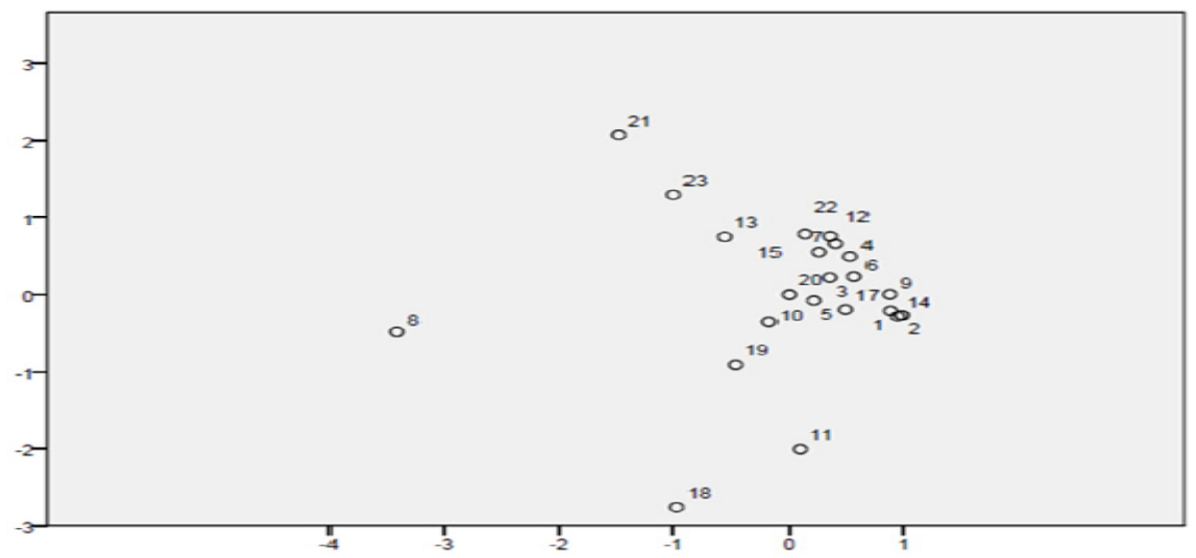

Figure 1. Degree of satisfaction of 23 individual companies

(Source: Athor)

Note: Horizontal axis shows dimension 1, Nomalization of variable component while vertical axis shows Dimention 2.

Identification 1-11 are companies that are geographically close to the academic partners classified as Table 1: Three companies identified 1-3 are located on university campus and eight companies 4-11 are tenant companies based on science park. Identification 12-23 are not geographically closed to higher education institutes and operate at independent site. 


\section{Interview with UK University Researchers}

\section{Benefits and Incentives for University Researchers to Work with Japanese firms}

\subsection{Interviews with UK Academics}

The interviewees were distinguished professors working with Japanese companies identified as 1, 2, 5, and 9 in Figure 1 whose responses indicate higher satisfaction rates. The six selected interviewees are affiliated with the top UK universities who have the highest positions among the local employees, serving as key decision makers for future research themes as well as managing all scientific and technological issues.

The interviews were carried out to explore the following issues:

-What benefits do local academics expect and actually obtain from collaboration?

-How does the distinguished R\&D management employed by Japanese companies affect the course of collaboration? How have prioritised research themes usually been selected? How often does academics have a meeting with a partnering company in orer to evaluate the progress and outcomes derived from such collaboration?

-Additional questions asked whether the interviewees have been working with other universities and companies and whether they have been involved with EU projects with broader partners in Europe.

Table 4 is the list of interviewees who are working with Japanese companies identified as 1, 2, 5, and 9 and shown in Table 1, including three professors of the University of Cambridge working with Japanese ICT companies based on campus and in a science park; one professor of Oxford University working with a Japanese automobile company which owns R\&D centre in science park; one professor of Imperial College working with Japanese pharmaceutical and chemical companies; and one professor of University College London working with a Japanese pharmaceutical company based on campus. All of them have rich experience in working with industries originating not only in Japan but also in other European countries.

Table 4. List of intervewees working with Japanese companies

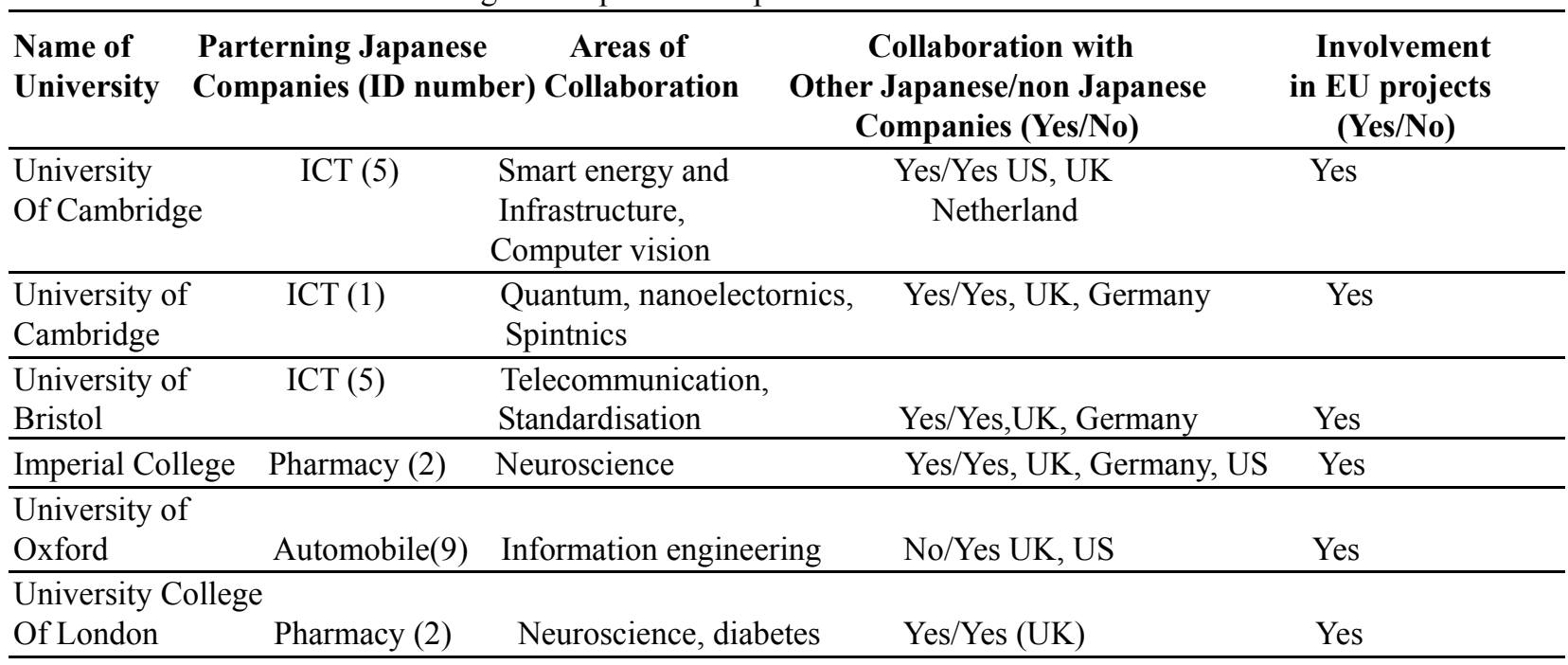

(Source: Author)

\section{Summary findings from interviews with academics}

> Japanese companies prefer to establish a personal link by sending a secondment to UK institutes with one year contract. The primary aim of these Japanese companies is to gain an understanding of UK researchers' capabilities and skills in specific research areas. On the other hand, UK academics prefer to establish a long-term collaboration matched with their own funding resources available in the UK.

$>$ Japanese companies rely upon their own investigation through their personal networks and identify the most appropriate academic partners. The approach is usually made directly by the Japanese side. Japanese companies tend to start trial collaborations, so it sometimes requires quite a while to engage in multiyear projects. In the early stages, they are less interested in expanding co-funding by matching the funds from British organisations, such as research councils, while UK academia suggests launching project-based collaboration. 
$>$ Most UK domestic companies, regardless of the size of their R\&D expenditures and sales, and employees do not own their in-house R\&D facilities, unlike Japanese companies. Thus, it is not unusual for open innovation in working with higher education institutes happens more naturally, and university researchers need such collaboration to survive themselves and to expand the size of their own laboratories. The conflicts of interest between the industrial and academic sectors appear as more serious issue in Japan compared to those in UK.

$>$ The expected outcomes through collaboration with Japanese companies are synergies from multinational collaboration, so UK entities prefer more strategic involvement with long-term vision. Working with Japanese companies is important not merely for research incentives and funding opportunities but also for political purposes, which are very important. Working with Japanese companies provides more opportunities to join EU projects with a great deal of funding. The overall picture of Japanese companies' global strategies is not very clear to UK academics. The critical decision making is strictly centralized.

$>$ Dealing with complexities in new areas of research requires a multidisciplinary approach. University-business collaboration is essential in this respect, as it provides incentives for university researchers and especially young students, widening motivation to engage in more applied areas of research. The strength of ties and level of trust in each other in collaborative $R \& D$ is found to have a positive impact on information and knowledge transfer, which may generate spillover effects.

\section{Conclusion}

This study identifies the 23 most proactive Japanese companies that have established R\&D centres in the UK, maintaining and intensifying their collaboration with local higher education institutes. Consumer electronics and information are the most proactive sectors in terms of inward investors towards UK throughout the 1990s. Japanese companies' R\&D centres are concentrated in eastern and south-eastern England, a region well known as a UK innovation hot spot where many prestigious universities and global companies are based.

The results of the questionnaire demonstrate that the good research reputation and research facilities are the key factors for Japanese companies in identifying the most suitable partners in the UK. Most companies perceive highly qualified human resources and new knowledge and ideas as essential for future products based in the UK. In terms of the pattern of actual collaborative activities, a majority of companies undertake informal contact with academics and sponsor research trials or projects.

The above Japanese companies identified as most proactive in university-business collaboration are classified into three categories based on their locations in science parks, on campuses or on independent sites. The results show that companies carefully choose a location that complies with their R\&D global strategies. Japanese companies tend to maintain their integrated organisational and business models from their home country. However, the results from the questionnaires and interviews in this study show that these companies have developed their organisational capacity by embedding themselves in local innovation networks, utilising the locational advantages of an excellent research environment.

As highlighted in the interviews with six senior professors working with Japanese ICT, automobile, and pharmaceutical companies, the Japanese companies have strong personal links with UK academia and gain some advantages and privileges in terms of human resources, excellent facilities and related business support. These companies have successfully explored a wider research network through strong personal links and other related research funding agencies and the scientific community. It can be summarised that some degree of personal contact or oral communication is necessary for knowledge to be effectively transferred. Moreover, most interviewees were involved with EU projects, which serve as a hub in the European research network.

In short, Japanese companies located in regions where higher education institutes are concentrated are more likely to be innovative than companies located elsewhere due to the benefits they gain from the knowledge that emerges from these sources. Knowledge spillovers from university research to firms are highly localised. Geographical clustering and the proximity of actors is important for the generation of knowledge transfer and related spillovers.

In short, the findings from this study can help managers at global companies that engage in technology-intensive $R \& D$ who are keen to internationalise their $R \& D$ strategies to access an excellent knowledge base. The experts directly involved with human resource and organisational management will value the outcomes of this research as good models for future decision making and in the process of improving returns over cost and the capabilities of skilled workers. Moreover, the UK government perceives the increased inward investment from foreign countries as a catalyst for creating new jobs and for economic growth, as well as promoting knowledge-based innovation. In this 
sense, this study highlights the need for further institutional arrangements to draw foreign companies and efforts to capitalise on foreign-hosted firms.

Yet, this study could not fully demonstrate the impact of Japanese companies' R\&D with UK higher education institutes on local regional innovation through a comparative study with other proactive investors from the United States and other European countries. Looking into more detail concerning ongoing collaborations led by on- and off-park companies, future studies may need to clarify what policy incentives are necessary for the host country to improve performance and promote regional innovation derived from the internationalised university-industry collaboration.

\section{References}

Abramovsky, L., Harrison, R., \& Simpson, H. (2007). University research and the loation of business R\&D. The Economic Journal, 117, 114-141. http://dx.doi.org/10.1111/j.1468-0297.2007.02038.x

Asakawa, K. (2001). Organizational tension in international R\&D management: the case of Japanese firms. Research Policy, 30, 735-757. http://dx.doi.org/10.1016/S0048-7333(00)00103-7

Bloom, N., \& Griffith, R. (2001). The Internaionalisation of UK R\&D. Fiscal Studies, 22(3), 337-355. http://dx.doi.org/10.1111/j.1475-5890.2001.tb00045.x

Duystaers, G., \& Hagedoorn, J. (1996). Internationalization of corporate tehnology through strategic partnering: an empirical investigation. Research Policy, 25, 1-12. http://dx.doi.org/10.1016/0048-7333(94)00803-5

Kuemmerle, W. (1999). The drivers of foreign direct investment into research and development: an empirical investigation. Journal of International Business Studies, 30, 1-24. http://dx.doi.org/10.1057/palgrave.jibs. 8490058

Kumar, N. (2001). Determinants of location of overseas R\&D activity of multinational enterprises: the case of US\&Japanese corporations. Research Policy, 30, 159-174. http://dx.doi.org/10.1016/S0048-7333(99)00102-X

Lam, A. (2003). Organizational learning in multinationals: R\&D network of Japanese and US MNEs in UK. Journal of Management Studies, 40, 673-703. http://dx.doi.org/10.1111/1467-6486.00356

Lambert, R. (2003). Lambert Review of Business-University Collaboration. HM Treasury.

Laursen, K., Reichstein, T., \& Ammon Salter, A. (2011, April). Exploring the Effect of Geographical Proximity and University Quality on University-Industry Collaboration in the United Kingdom. Regional Studies, 45(4), 507-523, Routledge. http://dx.doi.org/10.1080/00343400903401618

McGuckin, R., Inklaar, R., Ark, B., \& Dougherty, M. (2005). The Structure of Business R\&D: Recent Trends and Measurement Implications, Paper for Conference on "The Measurement and Analysis of Innovation and Productivity Growth", 10-11 November, University of Groningen.

Mowery, D. (1998). The changing structure of the US national innovation system: implication for international conflict and cooperation in R\&D policy. Research Policy, 27, 639-654. http://dx.doi.org/10.1016/S0048-7333(98)00060-2

Nagaoka, S., Hosono, M., Akaike, S., \& Nishimura, J. (2013). University-Business Collaboration for Knowledge Creation and Innovation. IIR Working Paper 13-14, Hitotsubashi University Institute of Innovation Research.

Odagiri, H. (2003). Transaction costs and capabilities as determinant of the R\&D boundaries of the firm: a case study of the ten largest pharmaceutical firms in Japan. Managerial and Decision Economics, 24, 187-211. http://dx.doi.org/10.1002/mde.1083

OECD. (2012). Technology and Industry Outlook 2012.

Ostry, S., \& Nelson, R. (1995). Techno-nationalism and thno-globalism: Conflict and Cooperation. Brookings Institution.

Patel, P., \& Vega, M. (1999). Pattern of internationalization of corporate technology: location vs. home country advantage. Research Policy, 28, 145-155. http://dx.doi.org/10.1016/S0048-7333(98)00117-6

Pearce, R., \& Papanastassiou, M. (1999). Overseas R\&D and strategic evolution of MNEs: evidence from laboratories in the UK. Research Policy, 28, 23-41 http://dx.doi.org/10.1016/S0048-7333(98)00104-8

Pfirmann, O. (1995). Path analysis and regional development: factors affecting R\&D in West German small and medium sized firms. Regional Studies, 29, 605-618. http://dx.doi.org/10.1080/00343409512331349223 
Poon, T.S.C. (1998). Inter-firm networks and industrial development in the global manufacturing system: lessons from Taiwan. Economic and Labour Relations Review, 9, 262-284. http://dx.doi.org/10.1177/103530469800900206

Shimazutani, S., \& Toda, Y. (2008). What determine overseas R\&D activities? The case of Japanese international firms. Research Policy, 37. http://dx.doi.org/10.1016/j.respol.2007.11.010

Suzuki, J., Goto, A., \& Baba, Y. (2007). Research activities of university researchers and university-industry collaboration. In Baba, Y. (Ed.), Empirical Study on University-Industry Collaboration. University of Tokyo Press.

Suzuki, S., Belderbos, R., Hyeog, R., \& Fukao, K. (2012) . The impact of host country's university research and University-Industry collaboration on the location of R\&D; Evidence from Japanese multinational firms. RIETI Discussion Paper, 12-E-080.

Teece, D. (2003). Essays in Technology Management and Policy: Selected Paper of David Teece. World Scientific, London.

UK Department of Business, Innovation and Skills. (2011). International Comparative Performance of the UK Research Base.

UK Department of Innovation, Universities, and Skills. (2008). Innovation Nation, White Paper.

UK Trade and Investment. (2010). Details of Japanese Companies in the UK. 